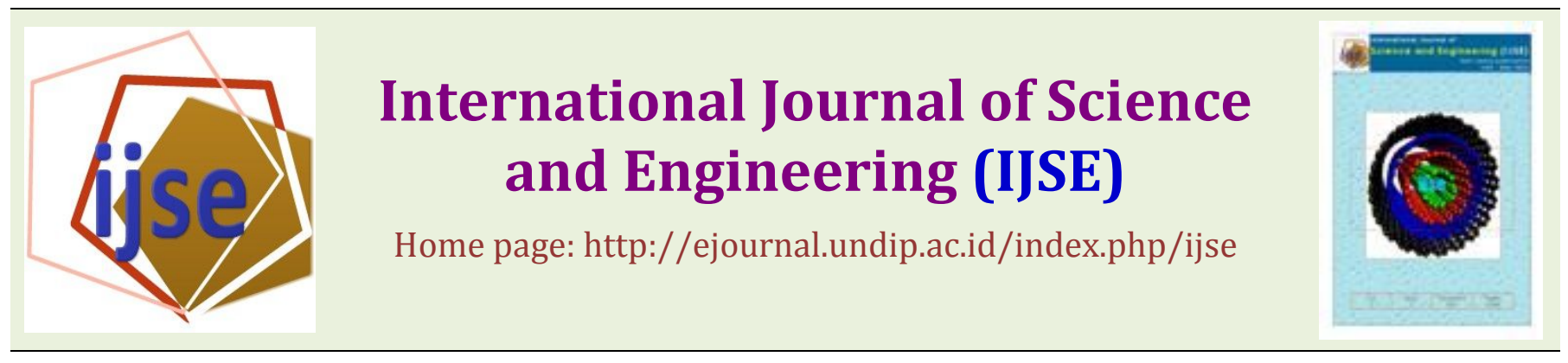

\title{
Performance of indigenous chicken under intensive rearing with various litter materials
}

\author{
M. Sulistyoningsih ${ }^{*} \# 1$, D. Sunarti ${ }^{* 2}$, E. Suprijatna ${ }^{* 3}$, and Isroli ${ }^{* 4}$ \\ ${ }^{*}$ Faculty of Animal Agriculture, Diponegoro University \\ Tembalang Campus, Semarang 50275 - Indonesia \\ \#FPMIPA IKIP PGRI Semarang-Indonesia \\ ${ }^{1}$ meisulis@yahoo.co.id; ${ }^{2}$ dwisunarti@gmail.com; ${ }^{3}$ edjengs@yahoo.com; ${ }^{4}$ isroliundip02@yahoo.com
}

\begin{abstract}
The purpose of the research was to obtain information regarding the performance of indigenous chicken under intensive rearing. The performance criteria were the increasing body abdominal weight, fat, rectal temperature, and the indigenous chicken's mortality within the 5-week starter phase treatment. Research was conducted using 108 Day Old Chick (DOC). Data variance was analysed based on the split plot design (3 types of cage litter materials, 5 weeks of data collection, and 4 replications) for weight gain and abdominal fat parameters, and completely randomized design in time for rectal temperature. The result indicated a significant effect of different litter materials towards weight gain $(P<0.01)$, the highest body weight was found on chicken treated with rice straw litter; there was no effect of litter material on abdominal fat percentage; there was a significant effect $(P<0.01)$ of age towards rectal temperature; and there were no interactions between litter material with age, on body weight gain, abdominal fat, and rectal temperature. Chickens under intensive rearing in rice straw floored cages were proven to have a mortality rate reduced by $3.7 \%$ in the starter phase.
\end{abstract}

[Keywords - intensive rearing; performance; litter material; indigenous chicken]

\section{INTRODUCTION}

Indigenous chickens are local chickens scattered throughout parts of Indonesia, usually consumed the community and have heterogeneous characteristics. Indigenous chicken are domesticated from jungle fowl that are widely spread in different regions of Bangladesh, Pakistan, India, and Sri Lanka. Indigenous chickens are classified as warm-blooded animals and will seek to maintain their body temperature in order to carry out normal physiological functions (Iswanto, 2008).

Rectal temperature is often used as a physiological parameter in poultry researches, as most chickens under distress or discomfort are identified by their increased body temperature. There are external and internal factors that can result in discomfort in chickens. External factors include lighting, hunger, thirst, caging, ventilation, vaccination, and sudden weather changes. Internal factors include changes in the nervous system, sensory system, and endocrine systems.

Zainudin (2005) said, that local chicken breeding pattern in villages is more extensive way $80 \%$ ) than intensively or semi intensive $(20 \%)$. The results showed chicken performance was better maintenanced in intensive and semi intensive.

Cages and henhouses were intended to create comfort and protection, so that the food consumed could be optimally utilized for growth and production. In villages, indigenous chickens are traditionally reared outside cages (released freely). This method exposes the chickens to many risks, and is considered not economical.

The type of cage flooring used was one of the environmental elements influencing poultry productivity. There were two main types of cage flooring; litter flooring and distantly spaced flooring. Litter flooring could be made from rice husk, wood shavings or sawdust. Widjastuti et al. (2005) observed that litter flooring had an effect on food intake on Merawang chickens.

Mugiyono (2001), gave criteria for choosing a good litter material to have an absorber effect, free dirt/dust, always available, free from poison, relatively cheap, widely available in the environment, and easy to clean.

This research was intended to study the influence of a pedestal litter against performance indigenous chicken, seen from the increasing body weight, abdominal fat, rectal temperature and mortality for 5 weeks.

\section{MATERIALS AND METHODS}

This research was conducted for 5 weeks. 108 DOC indigenous chickens were used in this research. The cage dimension was $2.20 \times 1 \times 0.6$ metre cubic (lxwxh). The cage was staged 50 centimeters high off the ground, with wire walls covered by plastic as insulators at the beginning of rearing. The density of each 
cage was 9 chicks per experimental unit. Each cage was equipped with a set of lights, thermostat $\left({ }^{\circ} \mathrm{C}\right)$, and thermometer. Cages were fumigated 2 days before the arrival of the DOCs.

The study used a split plot design with 3 types of cage flooring (rice husk, sawdust, and rice straw) and age; 6 data acquisition points (day 1, weeks 1,2,3,4,5), each with 4 replications. During the first ten days, sheets of newspaper were used as a base for the litter flooring, due to the condition of chicks that were still small and weak. Insulation plastic that wraped the wire cages on each side, were gradually removed, based on the cage temperatur suitable for the chickens as they grew.

Parameters observed in this study were the increasing body weight, abdominal fat, mortality and rectal temperature. The incresing body weight and abdominal fat data was acquired using digital scale with $0.001 \mathrm{~g}$ sensitivity. Abdominal fat were weighed each week and compared to the weight of the chicken. Rectal temperature data was acquired using a digital thermometer every week. with $0.1^{\circ} \mathrm{C}$ sensitivity. Mortality data was acquired by recording the number of chickens that died in each litter, for the 5 weeks of the study.

Data was acquired every week, totalling a 6 time data collection each for Weights again, abdominal fat and rectal temperature; on the first day and weeks $1,2,3,4$, and 5 . The data was analyzed using variance analysis, followed by Duncan test.

\section{RESULTS AND DISCUSSIONS}

\section{A. The Increasing Body Weight}

This research showed a significant effect $(P$ $<0.01$ ) of three litter floor type towards weight gain, as shown in Table 1.

Table 1. Average The Increasing Body Weight of Chicken in 5

\begin{tabular}{lll}
\multicolumn{2}{c}{ Weeks } \\
\hline \hline Treatment & Treatment level & \multicolumn{1}{c}{ Average } \\
litter & & g/ chick/ week \\
& rice straw/ a3 & $43.86^{\mathrm{a}}$ \\
& rice husk/ a1 & $37.71^{\mathrm{b}}$ \\
& sawdust/ a & $35.31^{\mathrm{b}}$ \\
age & week 5 & $52.45^{\mathrm{a}}$ \\
& week 4 & $49.55^{\mathrm{ab}}$ \\
& week 3 & $43.23^{\mathrm{ab}}$ \\
& week 2 & $34.86^{\mathrm{b}}$ \\
& week 1 & $14.72^{\mathrm{c}}$ \\
litter x age & & ns
\end{tabular}

Note: different superscript in the same column showed that there was a highly significant $(\mathrm{P}<0,01)$; ns : non significant

This data was supported by the feed consumption and feed conversion rate (FCR) as shown in table 2 . The highest mean of increasing body weight was found in chickens reared with rice straw flooring with feed consumption and FCR are best. Meanwhile chickens reared with litter flooring made from rice husk and sawdust showed similar results, although descriptively the smallest weight gain was observed in chickens reared with sawdust litter flooring. This was believed due to the inability of sawdust flooring to absorb liquid, causing discomfort for the chickens. Rice husk was equally unable to absorb liquid well; moreover rice husk could easily fly when the chickens scratched the floorings, causing a potential respiratory problem and discomfort for the chickens. With rice husk flooring, the chickens could potentially suffer from sour crop / slow crop, which disturbed the digestion of food to the stomach, due to accidental mixing of litter material in the form of rice husk, wood shavings or sawdust inside the feed.

Table 2. The Influence of Litter Tray towards The Consumtion of Feed, FCR, Abdominal Fat, and Rectal Temperature on week 5

\begin{tabular}{clccc}
\hline \hline \multirow{2}{*}{ No. } & \multicolumn{1}{c}{ Parameters } & \multicolumn{3}{c}{ Average Treatment } \\
\cline { 3 - 5 } & & A1 & A2 & A3 \\
\hline 1 & $\begin{array}{l}\text { consumption of feed } \\
\text { (g/chick/day) }\end{array}$ & 16,22 & 14,90 & 15,19 \\
2 & $\begin{array}{l}\text { FCR (feed convention } \\
\text { rate) }\end{array}$ & 1,89 & 1,85 & 1,77 \\
3 & $\begin{array}{l}\text { abdominal fat (\%) } \\
4\end{array}$ & 0.66 & 0.61 & 0.73 \\
rectal temperature $\left({ }^{\circ} \mathrm{C}\right)$ & 40.51 & 40.65 & 40.75
\end{tabular}

The warm temperature in cages was very important for DOCs. At this stage, the Cage also functioned as a brooder. Rice straw mat provided better comfort, good quality of air in the cage and warmth compared to the other two litter materials (rice husk and sawdust). Comfort was a significant contributing factor for the DOC to ensure production quality in terms of weights gain; this was particularly observed since the third week as shown in Table 2. The results showed no interaction between litter base materials and age towards the chicken's body weights

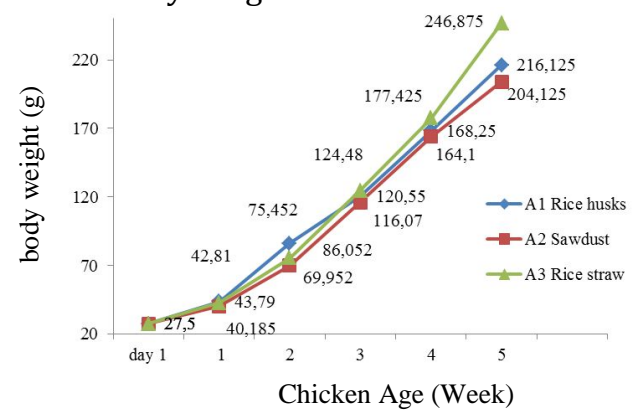

Fig. 1 Indigenous chicken's Body Weight Weekly Average for 5 Weeks Weight of Litter Base (g)

Indigenous chickens are often considered uneconomical for business, due to its low productivity, slow growth, low egg production, and a relatively high mortality rate. Some researchers have shown that little changes in conventional rearing could potentially increase productivity in indigenous chickens (Das et al. , 2008)

Indigenous chicken in traditionally kept for 20 weeks, her weight only $746 \mathrm{~g}$, while intensively reared could reach $1435.5 \mathrm{~g}$. The improvement of management maintenance of chicken could increase performans indigenous chicken. The content of the fewest parasite found in rice straw compared to rice husk and sawdust (Setyawati, 2004), were the reasons why rice straw was better. 


\section{B. Abdominal Fat}

Abdominal fat is a form of tissue used to conserve energy in the body. The fat is gradually taken from blood circulation and is stored under the skin and the stomach (Hartini, 1986). Griffiths et al (1977) stated that abdominal fat is located around gizzard, intestine, extending to the ischium, around the stock fabricius and the abdominal cavity. Generally, abdominal fat accounts for $2-3 \%$ of the live weight. The percentages of abdominal fat in all the three treatments did not show a significant difference. This was good for both producers and consumers of indigenous chicken. The result showed that chickens reared with various litter material have relatively the same abdominal fat content, while the final body weight were significantly different and was best when reared with rice straw litter flooring (see Figure 1, Table 2, and Figure 2). Figure 2 showed the percentage of abdominal fat seem declined in week 5 , on a pedestal of rice straw. Abdominal fat on a indigenous chicken at the age of 5 weeks have not been able to demonstrate the difference, because genetically indigenous chicken is slow-growing birds. Increasing abdominal fat at chicken aged 5 weeks on a pedestal of sawdust and rice husk was very high ( $60 \%$ and $46.3 \%$ ), while on rice straw was only $17,2 \%$. This happened because a higher metabolisme occurred at the base of rice straw, as seen on the increasing body weight and body weight.

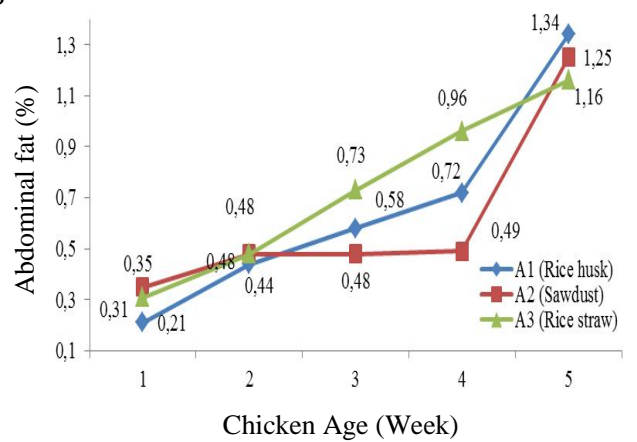

Fig. 2 The Influence of a Pedestal Litter and Aged against the Percentage of Abdominal Fat

Rearing with rice straw litter material was proven to be better, because it produced the highest body weight gain, while the percentage of fat produced relatively similar to using other litter material. Consumers would prefer this due to the fact that the increased body weight was not followed by an increased fat content. There was no interaction between the litter base materials with age on abdominal fat percentage.

\section{Rectal Temperature}

There are internal and external factors that can cause stress to chickens. External factors include lighting programs, hunger, thirst, cage system, ventilation, vaccination, and sudden weather changes. Internal factors include the nervous system, sensory system, and endocrine systems.
Poultry would react when it became uncomfortable environment such as changes in the material and the texture of the base enclosure, before giving a slow response (longterm), it would show a quick response in the form behavioral changes, such as increased perspiration, increased respiration, and also an increase in body temperature (Isroli, 1996).

Litter cages can serve as a protection against the cold of floor and as moisture absorber. Damp litter will accelerate microbial production and ammonia, which can cause discomfort for the chickens. Litter humidity is influenced by factors such as type of litter, air temperature, relative humidity and ventilation. A combination of these factors can result in litter conditions that are less favourable to the health of poultry and can have negative impact on the chicken's feet. High ammoniac content can occur in cages with litter flooring if not properly managed. High atmospheric ammonia level inside a confined space is detrimental to a chicken's health; it can induce irritation to the eyes of young chicks during the growth period in the first week.

Treatment pedestal litter results was not significant to the rectal temperature. Body heat the chicken came from endogenous heat due tu the metabolic processes of the body and the effect of the environmental factors of environment temperature, the temperature in the enclosure, humidity and wind speed. The average temperature in the enclosure in this research was relatively the same in the third litter trays (Table 3), with average temperature of environment $29.29 \pm 2.89^{\circ} \mathrm{C}$, dan moistuire environment $68.13 \pm 14.9 \%$. Suryana (2008) reported the results of his research on the influence of temperature and feed restriction on performance of chicken. The results showed that treatment with 3 levels of temperature of the enclosure $\left(28 \pm 1.78^{\circ} \mathrm{C} ; 31 \pm 1.38^{\circ} \mathrm{C}\right.$; $33 \pm 1.32^{\circ} \mathrm{C}$ ) did not give effect on rectal temperature of chickens.

Monteith and Mount (1978) said the temperature ideal for the maintenance of chicken was $18-24{ }^{\circ} \mathrm{C}$, with the humidity ideal was $55-75 \%$ (Nowland, 1978). The temperature in the enclosure in the author's research was higher than ideal (Table 3), but humidity was still ideal. This caused the chicken at age of 5 weeks had ideal temperature $\left(40.6-40.7^{\circ} \mathrm{C}\right.$, Suprijatna et al. 2002) due to the process of adaptation.

Table 3. Temperature and humidity environment and in a cage

\begin{tabular}{cccc}
\hline \hline Cage & $\begin{array}{c}\text { The average daily } \\
\text { temperature } \\
\text { enclosure }\left({ }^{\circ} \mathrm{C}\right)\end{array}$ & $\begin{array}{c}\text { The everage daily } \\
\text { temperature } \\
\text { environment }\left({ }^{\circ} \mathrm{C}\right)\end{array}$ & $\begin{array}{c}\text { The daily rate } \\
\text { of moisture } \\
(\%)\end{array}$ \\
\hline A1 & $30,18 \pm 3,21$ & $29,29 \pm 2,89$ & $68,13 \pm 14,90$ \\
A2 & $30,29 \pm 3,35$ & $29,29 \pm 2,89$ & $68,13 \pm 14,90$ \\
A3 & $30,64 \pm 3,24$ & $29,29 \pm 2,89$ & $68,13 \pm 14,90$ \\
\hline
\end{tabular}




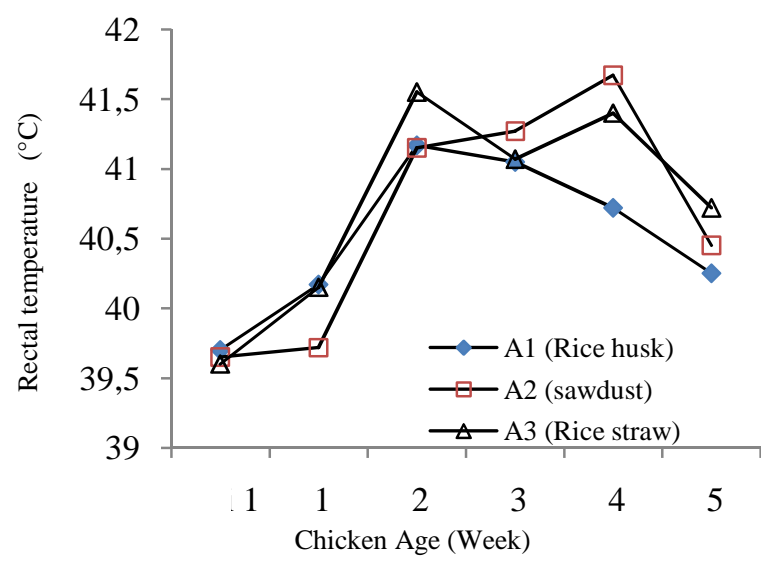

Fig. 3 The Influence of a Pedestal Litter and Aged against the Rectal Temperature

Rectal temperature is an indicator of stress/ discomfort in chickens; high rectal temperature indicates the presence of stress/ discomfort. This study showed little difference in rectal temperatures of chickens with different litter materials (Table 2). Significant difference $(\mathrm{P}<0.01)$ was seen in chickens of different week. Increased rectal temperatur occurred in the second week, third, and fourth. Rectal temperature in the fifth week showed a decline compared to the previous week. On the first day and first week, the rectal temperature of chickens was relatively low/ normal; this was because the cage flooring was the same for all cages (using sheets of newspapers). The newspapers were then removed on the 10th day, resulting in an increased rectal temperature on week 2, 3 and 4 . The chickens reacted to the change in flooring; from newspaper to litter based flooring. Changing from newspaper, which allowed them to move freely; to rice husk, sawdust and rice straws. Force the chickens to adapt to the new floorings with different textures, sizes and sensation to the feet. It understandable that these changes triggered a physiological response seen by increased rectal temperature, as stated by Isroli (1996).

Rectal temperature in the week 5 showed a decline compared to the previous. This means that in about five weeks, chickens had adapted to its new environment, including the litter flooring. However, the effect on body weight at the end of week 5 was not the same. There was no interaction between litter type and age on rectal temperature.

\section{Mortality}

The mortality rate of indigenous chickens reared in this study was very profitable for farmers. For comparison, the mortality rate of chickens reared traditionally/ freely released was 50.3\%; a semi-intensive rearing was at $42.6 \%$; and an intensive rearing mortality rate was at 27, 2\% (Suprijatna, 2010). This research provided an improved mortality rate of only $3.7 \%$ within 5 weeks of intensive rearing, with a total population of 108 DOC. The least death rate (only 1 chick) was seen with rice straw and rice hull litter flooring. Results shown in this research was almost equivalent to the results conducted on hybrid chickens from indigenous chicken and CP 808 broilers, which had a mortality rate of $3 \%$ during 7 weeks of rearing (Suharyanto, 2008).

\begin{tabular}{lcc}
\multicolumn{3}{c}{ Table 4. Mortality } \\
\hline \hline \multicolumn{1}{c}{ Treatment } & Amount & Percentage \\
\hline & -- chick - & -- \% --- \\
& & \\
Rice husk/ A1 & 1 & 0.92 \\
Sawdust/ A2 & 2 & 1.85 \\
Rice straw/ A3 & 1 & 0.92 \\
Total Amount & 4 & 3.7 \\
& & \\
\hline & Note: \\
The total population of 108 chickens in cages DOC \\
Rearing age of 5 weeks
\end{tabular}

The low mortality rate in this study showed that intensive rearing of indigenous chicken proved to be more profitable for farmers and communities around the chicken farm. General public sanitary was better because chickens were not free to roam in the villages. The chicken's health and well being was also better controlled, as the chickens did not interact with wild birds; vaccinations and the drug treatments (deworming) could be carried out regularly. The above rearing management, if done correctly, could improve the quality of production. Intensive rearing in a staged cage using litter based flooring was proven to reduce mortality.

\section{CONCLUSION}

This research result indicated a pedestal litter the best was rice straw, based on the increasing body weight, body weight, the percentage of abdominal fat, the rectal temperature, and mortality for the maintenance of indigenous chicken for 5 weeks.

\section{REFERENCES}

[1]. Anisuzzaman and S.D. Chondhury. 1995. Use of four types of "litter" for rearing broiler. Poultry Sci. 37 : 541 - 545.

doi : http://scialert.net/abstract/?doi=pjbs.2001.1565.1567

[2]. Appleby, M. C. , B. O. Hughes and H. A. Elson. 1992. Poultry Production System : Behaviour, Management and Welfare. C. A. B. International, Wallingford.

doi : http://dx.doi.org/10.1017/500218596000776656

[3]. Austic, R. E. and M. C. Nesheim. 1990. Poultry Production. 3rd edition. Lea \&Febiger.Philadelpia.London

[4]. Daliani,S.D., Wulandari W. A., D. Zainudin, and Gunawan. 2005. Summary of results of studies range chicken in Bengkulu Regency. National Workshop on Technological Innovation Development Of Indigenous Chicken: p $272-279$

[5]. Das, S.C., S.D. Chowdhury, M.A. Khatun, M.Nishibori, N. Isobe and Y. Yoshimura. 2008. Poultry production profile and expected future proyection in Bangladesh. World's Poultry Sci.J. 64 : 99-118. doi : doi : 10.1017/Soo43933907001754

[6]. Gasperz, V. 1991. Analysis Techniques in The Research of The Experiment. Tarsito. Bandung.

[7]. Griffiths. L., S. Leeson and J. D. Summers. 1977. Fat deposition in broiler : Effect of dietary energy to protein balance and early life caloric restriction on productive performance and abdominal fat pad size. Poultry Sci. 56 : $638-646$. doi : 10.3382/ps.0560638 
[8]. Gunawan and D.T.H. Sihombing. 2004. The influence of the high environmental temperature against physiological state and the production of Indegenous chicken. Wartazoa 14 (1) : 31 - 38.

[9]. Hartini.1986. The influence of time restrictions of feeding against a wedge commercial, the organs within and abdominal broiler chicken fat. Karya Ilmiah. Faculty of Animal Agriculture IPB. Bogor.

[10]. Insulistyowati, A., P. Rahaju, and Afriani. 2005. Parameters hematologis the indigenous chick that are reared on two types of the floor of the cage. Proceedings The National Seminar on Poultry Lokal III. Diponegoro University. Semarang. p $92-93$.

[11]. Isroli.1996. The arrangement of energy consumption in livestock . Sainteks 3 (2): 64-72.

[12]. Iswanto, H. 2008. Kampung Chicken. Agromedia Pustaka. Jakarta.

[13]. Monteith, J.L. and L.E. Mount. 1978. Heat Lost from Animal and Man. Butherworth and Co. London. Doi : 10.1016/S0301-6226(01)00330-X

[14]. Mugiyono, S. 2001. The influence of litter against the appearance of productivity and the quality of chicken. Faculty of Animal Agriculture. Jenderal Soedirman University. Research not published.

[15]. Muharlien, Achmanu, and R. Rachmawati. 2011. Increasing the production of broiler by setting the proportion of chaff, sand, and lime as a litter. J. Ternak Tropika. 12 (1) : $38-45$.

[16]. Nowland, W.J. 1978. Modern Poultry Management in Australia. Rugby limited. Adelaide.

[17]. Olanrewaju, H. A. , W. W. Miller, W. R. Maslin, J. P. Thaxton, W. A. Dozier, J. Purswell, and S. L. Branton. 2007. Interactive effects of ammonia and light intensity on ocular, fear and leg health in broiler chickens. Int. J. Poultry Sci. 6 :762-769.

doi : http://dx.doi.org/10.1590/S1516-35982008001300028

[18]. Prayitno, D. S. 1994. The Effect of Colour and Intensity of Light on The Behaviour and Performance of Broiler. Disertation. University of Wales.

[19]. Resnawati, H. and Ida A. K. Bintang. 2005 Productivity of local chicken that are reared intensively. Proceeding Workshop National Technological Innovation The Development Of Indigenous Chicken. : p $121-125$.
[20]. Setioko, A. R. and S. Iskandar. 2005. Review the results of the research and development of technologies in support of indigenous chicken. Proceeding Workshop National Technological Innovation The Development Of Indigenous Chicken. p $10-19$.

[21]. Siregar, A. P. 1981. Techniques of Raising Broiler in Indonesia. Margie Group. Jakarta.

[22]. Suharyanto, A. A. 2008. Harvest of Kampung Chicken in Seven Weeks. Panebar Swadaya. Jakarta.

[23]. Sukamto, B. 1997. Energy and Protein Needs Based on The Efficiency in Protein Use with The Manifestation of Kedu Chicken Production Performance. Disertation. Padjadjaran University. Bandung.

[24]. Suprijatna, E. 1992. Ammonia pollution in the chicken coop, their impact on performance and how to solved it. Sintesis 4 : 43-51.

[25]. Suprijatna, E. U. Atmomarsono dan Ruhyat, K. 2005. Basic Science Livestock Poultry. Panebar Swadaya. Yogyakarta.

[26]. Suprijatna, E. 2010. The Development Strategy Of Indigeneous Chicken Farms In Indonesia. Inaugural Speech Professor of Faculty of Animal Agriculture. Diponegoro University. Semarang.

[27]. Suryana, H. 2008. The Influence of Temperature and Ration Restriction on Broiler Chicken Performance. Thesis. Andalas University. Padang.

[28]. Widjastuti, T., dan D. Garnida. 2005. Performance evaluation of merawang chicken growth phase (12 week) on the cage wire system and the system of litter with different energyprotein balance in the ration. Proceeding Workshop National Technological Innovation The Development of Indigeneous Chicken : p 51 - 55.

[29]. Yamamoto, Y. Namikawa,T. , Okada, I. Nishibori, M. Mansjoer, S. S. and Martoyo, H. 1996. Genetic studies on native chicken in Indonesia. Asian-Aust J. Anim. Sci. $9: 405-410$.

[30]. Zainuddin, D. 2005. Utilization of local resources for feeding strategy and improved management of Indigeneous chicken. Research Center For Livestock (Animal Research Institute), Bogor. Proceeding Workshop National Technological Innovation The Development of Indigeneous Chicken. Semarang. : p $32-41$. 